P-ISSN: 2774-4574; E-ISSN: 2774-4582 TRILOGI, 2(1), Januari-April 2021 (81-93) @2021 Lembaga Penerbitan, Penelitian, dan Pengabdian kepada Masyarakat (LP3M) Universitas Nurul Jadid Paiton Probolinggo DOI: https://doi.org/

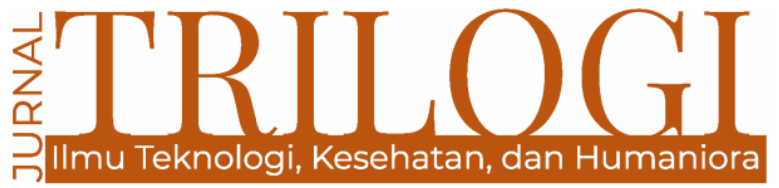

\title{
INKULTURASI PENDIDIKAN AGAMA ISLAM DI TENGAH PERBEDAAN MULTIKULTUR RAS, SUKU, DAN AGAMA: Studi Kasus di Yayasan Bali Bina Insani Tabanan Bali
}

\author{
Hirtsul Arifin \\ Sekolah Tinggi Agama Islam Istiqlal, Buleleng, Bali \\ hirtsularifin123@gmail.com
}

\begin{abstract}
Multicultural education remains an important issue today, moreover social conditions are faced with the challenges of the radicalism movement which is increasingly open. Multicultural education can be used as a movement that can counter the radicalism movement. This study parses the problem of multicultural education at the Bina Insani Bali Boarding School. Conceptually, multicultural education at the Bali Bina Insani (BBI) Islamic Boarding School is characterized by diverse civitas. There are Muslim and non-Muslim (Hindu) teachers and employees. The students also varied. Subject matter is inclusive-tolerant. The learning approaches and strategies are varied. The evaluation is comprehensive. The environment is plural.The "BBI Pesantren"respects differences and puts forward similarities. It has a capital of insight, attitude and tolerant behavior that is organic. Through multicultural education, "BBI Pesantren"is well received by the majority Hindu community. "BBI pesantren"is growing institutionally; the fabric of social cooperation between the community and "BBI Pesantren"; the surrounding community participates in controlling the behavior of students. The response of the surrounding community is also good, so they can live in harmony and work together in mutual symbiosis.
\end{abstract}

Keywords: multicultural education, concept, practice

\section{Abstrak}

Pendidikan multikultural tetap menjadi isu penting dewasa ini, apalagi kondisi sosial dihadapkan pada tantangan gerakan radikalisme yang semakin terbuka. Pendidikan multikultural dapat dijadikan sebagai gerakan anti radikalisme. Tulisan ini mengurai permasalahan pendidikan multikultural di Pesantren Bali Bina Insani. Secara konsep, pendidikan multikultural di Pesantren Bali Bina Insani (BBI) ditandai dengan civitas yang beragam. Terdapat guru dan pegawai Muslim dan non Muslim (Hindu). Santri-santri juga beragam. Materi pelajaran bersifat inklusif-toleran. Pendekatan dan strategi pembelajarannya variatif. Evaluasinya komprehensif. Lingkungannya plural. Pesantren BBI menghargai perbedaan dan mengedepankan persamaan. Ia memiliki wawasan, sikap dan perilaku toleransi organik. Pendidikan multikultural didesain sebagai strategi adaptasi di daerah minoritas Muslim. Melalui pendidikan multikultural, Pesantren BBI diterima dengan baik oleh masyarakat Hindu. Ia tumbuh berkembang secara kelembagaan; adanya jalinan kerjasama sosial antara masyarakat dengan Pesantren BBI; masyarakat berpartisipasi dalam mengontrol perilaku santri. Respon masyarakat juga baik, mereka hidup rukun dan saling bekerjasama secara mutual simbiosis.

Katakunci: pendidikan multikultural, konsep, praktik 


\section{Pendahuluan}

Konsep masyarakat majemuk atau masyarakat plural seringkali dibicarakan bersama-sama dengan konsep masyarakat multikultural, karena keduanya sama-sama menggambarkan keanekaragaman sosial dan kebudayaan. Akan tetapi, apabila istilah plural dan multikultural ini ditambahi imbuhan isme maka pengertian keduanya akan berbeda. Pluralisme berarti pemahaman atau cara pandang keanekaragaman yang menekankan entitas perbedaan setiap masyarakat satu sama lain dan kurang memperhatikan interaksinya, sedangkan multikulturalisme adalah pemahaman dan cara pandang yang menekankan interaksi dengan memperhatikan keberadaan setiap kebudayaan sebagai entitas yang memiliki hak-hak yang setara. Dari konsep multikulturalisme inilah kemudian muncul gagasan normatif mengenai kerukunan, toleransi, saling menghargai perbedaan dan hak-hak masing-masing kebudayaan penyusun suatu bangsa (Syaifuddin, 2006).

Tak ada yang meragukan bahwa Indonesia negara besar dengan keragaman budaya, suku, dan agama yang berbeda-beda di dalamnya. Dari itu menurut Maskuri, memiliki pemahaman konsep multikulturalisme yang baik dan menyadarinya sangat penting untuk kontek ke-Indonesia-an. Paham multikulturalisme menurutnya, harus menjunjung Bhinneka Tunggal Ika, rakyat Indonesia harus mampu menghargai perbedaan keragaman suku, budaya, agama dan etnis. Bila keragaman budaya itu dipahami dengan baik maka akan tercipta Indonesia yang damai dan stabil. Namun sebaliknya, kegagalan memahami dan menerima keragaman budaya (multikultural), utamanya dalam hal perbedaan agama akan berakibat fatal, yaitu timbulnya perpecahan. Agar kita sukses menghadapi kehidupan dengan keragaman, Maskuri memberikan nasehat sebagai berikut: "Kita harus meyakini adanya Tuhan dalam agama, namun kita juga harus meyakini adanya agama lain selain yang kita yakini" (Maskuri, 2017).

Multikulturalitas bangsa merupakan realitas dalam komunitas indonesia yang tak mungkin dipungkiri dan dihindari, bangsa Indonesia yang terdiri dari ribuan pulau, ratusan bahasa, suku, bangsa dan agama. Kondisi ini merupakan berkah dan hikmah apabila kita mampu mengaransemennya dalam sebuah keterpaduan yang menghasilkan keindahan dan kekuatan, tetapi juga bisa menjadi musibah disintregasi bangsa manakala multikulturalitasi itu tidak terakomodasi dengan baik. Oleh karena itu, dapat dimengerti bahwa desain dari pendirian bangsa dan negara kesatuan Republik Indonesia adalah negara yang bersatu, berdaulat adil dan makmur, untuk mewujudkan sebuah negara kebangsaan "yang bersifat demokratis dan yang hendak menyelenggarakan keadilan sosial dan perikemanusiaan". Sebab para pendiri bangsa Indonesia ini meyakini bahwa hanya melalui sebuah negara kebangsaan, demokrasi, keadilan sosial, dan perikemanusiaan (HAM) yang kemudian dipadu dengan kesadaran berketuhanan Yang Maha Esa, kemajemukan pluralitas bangsa ini bermakna positif. Seperti cuplikan pidato Bung Karno pada tanggal 1 juni 1945, "Negara Indonesia bukan satu Negara untuk satu orang, bukan satu negara untuk satu golongan, walaupun golongan kaya. Tetapi kita mendirikan negara " semua buat semua, satu buat semua (Shofa, 2016).

Tindakan dan sikap saling menghormati dan tidak saling menganggu dalam perbedaan sangat tidak bertentangan dalam ajaran agama Islam maupun agama lainnya, dijelaskan di dalam QS Mumtahanah ayat 8-9:

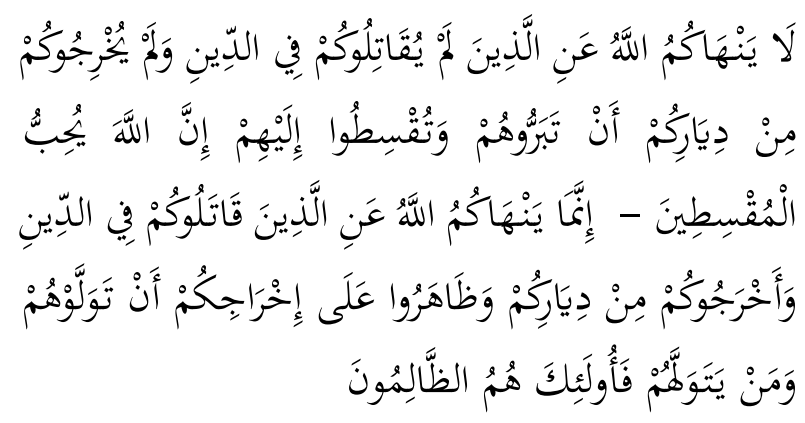

Artinya: "Allah tidak melarang kamu untuk berbuat baik dan Berlaku adil terhadap orangorang yang tiada memerangimu karena agama dan tidak (pula) mengusir kamu dari negerimu. Sesungguhnya Allah menyukai orang-orang yang Berlaku adil. Dan sesungguhnya Allah hanya melarang kamu menjadikan sebagai kawanmu orang-orang yang memerangimu karena agama dan mengusir dari negeriu. Dan membantu (orang lain) untuk mengusirmu. Dan barangsiapa menjadikan mereka sebagai kawan, maka mereka itulah orang-orang yang dzalim" (QS. AlMumtahanah

Dari ayat di atas telah jelas disampaikan bahwa bagi kita sebagai muslim diperkenankan (tidak ada larangan) untuk berbuat baik dan berlaku adil 
terhadap orang-orang (tidak seiman) selama mereka tidak memerangi kita dan tidak pula mengusir kita dari negeri kita. Bagaimana sikap dan tindakan kita yang lain sebagai muslim terhadap orang-orang yang tidak seiman dengan kita, tidak dapat dipungkiri bahwa manusia diciptakan di muka bumi ini bersuku-suku dan berbangsa sebagaimana dijelaskan di dalam AlQur'an QS Al-Hujurat ayat 13:

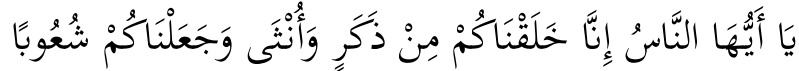

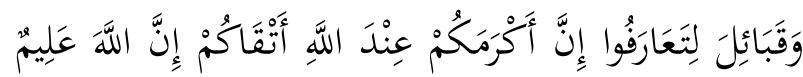

Artinya: Hai manusia, sesungguhnya Kami menciptakan kamu dari seorang laki-laki dan seorang perempuan dan menjadikan kamu berbangsa-bangsa dan bersuku-suku supaya kamu saling kenal-mengenal. Sesungguhnya orang yang paling mulia di antara kamu di sisi Allah ialah orang yang paling bertakwa di antara kamu. Sesungguhnya Allah Maha Mengetahui lagi Maha Mengenal.

Kerukunan antar umat beragam hadir di salah pulau negara Indonesaia, tepatnya di Tabanan pulau Bali. Unik rasanya ketika mendengar berita tentang adanya lembaga Pondok Pesantren yang berada di tengah-tengah lingkungan kampung adat. Ponpes biasanya berdiri berada di area penduduk yang mayoritas muslim dan diajar oleh guru muslim, misalnya Pondok Pesantren Darul Ulum gontor, Darun Najah Jakarta, Nurul Jadid Paiton Probolinggo, Salafiyah Safi'iyah Sukorejo Situbondo, Zainul Hasan Genggong Probolinggo dan lainya, rata rata berada di area penduduk yang mayoritas muslim.

Adalah Pondok Pesantren Bali Bina Insani yang terletak di tengah Desa adat di Tabanan Bali, di dalamnya terdapat lembaga pendidikan formal Madrasah Tsanawiyah dan Madrasah Aliyah setara dengan SLTP dan SLTA. Melalui observasi awal yang kami lakukan, terdapat hampir $50 \%$ gurunya berasal dari pemeluk agama Hindu. Karena berada di tengah masyarat desa adat Hindu, maka 100 \% masyarakatnya beragama hindu. Uniknya keberadaan Ponpes bisa berjalan dengan aman dan nyaman tanpa ada gangguan dari masyarakat sekitar. Terdapat 53 guru yang mengajar di Madrasah Tsanawiyah dan Aliyah Bali Bina Insani, 22 orang guru beragama Hindu.

Awal berdirinya Pondok Pesantren Bali Bina Insani, menurut penjelasan yang disampaikan oleh pengasuh Pesantren dan pendiri Ustadz Yulianto, sebelum Pesantren memiliki lembaga pendidikan formal, para santri sekolahnya di SMP
Negeri. Menurutnya pada tahun 1995, kepala sekolah SMP Negeri datang kepada beliau dengan menyatakan dengan sebuah pertanyaan, kenapa pak haji tidak mendirikan SMP Islam sendiri?. Dijawab oleh beliau, sebenarnya keinginan tersebut ada, namun ketersediaan guru masih kurang dan belum memungkinkan. Persoalan guru gampang, kata kepala Sekolah SMP Negeri Tabanan, nanti kita bantu dengan mengirim guruguru yang ada di kami. Perasaan terharu dan gembira terpancar pada wajah Pengasuh Pondok Pesantren Bali Bina Insani. Pesantren ini memiliki 420 murid atau santri yang berasal dari Jakarta, NTT, NTT hingga Papua. Para guru yang berasal dari SMP Negeri Tabanan yang berjumlah 22 orang semuanya beragama Hindu.

Karena faktor-faktor nilai toleransi yang diajarkan dan diterapkan oleh Pesantren Bali Bani Insani, maka pada 09 Desember ahun 2016 dijadikan sebagai tempat kujungan dan percontohan kerukunan antar ummat beragama oleh Kementerian Luar Negeri saat dilaksanakan Bali Democrasy Forum, sebanyak 96 Duta Besar dan perwakilan NGO (Non-Governmental Organization) yang hadir pada saat itu. Ponpes yang bahasa pengantar dalam pembelajaran menggunakan bahasa Indonesia, Arab, dan Inggris ini mendapat predikat Tolerancy Boarding School dari Kementerian Luar Negeri Republik Indonesia.

Coronavirus Disease 2019 atau juga dikenal dengan istilah Covid-19 adalah jenis penyakit yang disebabkan oleh virus SARS-Cov-2. Pertama kali penyakit ini ditemukan di kota Wuhan, Cina pada tahun 2019. Pada 30 Januari 2020 World Health Organization (WHO) telah menyatakan COVID-19 sebagai darurat kesehatan masyarakat yang menjadi perhatian internasional (Dong et al., 2020). Dan pada awal tahun 2020 wabah ini juga mulai merebak di Indonesia.

Ada pembagian peran bagi guru yang berbeda agama untuk mengajar, bagi yang guru yang beragama Hindu mereka diberi materi pelajaran umum seperti bahasa Indonesia, geografi, ekonomi, matematika, kimia, dan fisika. Ketika ada hari Besar Agama baik Islam ataupun Hindu, diterapkan tradisi toleransi dimana mereka saling menghormari dan tidak saling mencela dan tidak saling menyalahkan. Bentuk-bentuk toleransi yang biasa dilakukan Seperti adanya Hari Besar Islam Hari Raya Idul Fitri dimana terdapat tradisi THR (Tunjangan hari Raya), maka semua guru yang berbeda agama memperolehnya. Begitu juga sebaliknya ketika ada Hari Besar Agama Hindu seperti Hari Raya Nyepi, maka pimpinan Pondok Peasntren meliburkan sekolah dan aktifitas belajar, misalnya satu hari sebelum Hari Raya 
Nyepi dilaksanakan ada pawai ogoh-ogoh, maka para siswa-siwi diliburkan atau sudah dipulangkan. Ini adalah salah satu contoh implemntasi toleransi antar ummat beragama. Menghormati minoritas dan menyayangi mayoritas.

Menarik untuk dilakukan penelitian pada fenomena yang telah dipaparkan diatas untuk mengetahui multikultur dalam pembagian peran bagi para tenaga pendidik pada lembaga Bali Bina Insani yang bebrbeda agama namun tetap dalam kebersamaan dan kedamaian serta saling berkontribusi dalam berbagi ilmu untuk kemajuan bangsa dan negara Indonesia.

\section{Metode}

Penelitian ini menggunakan pendekatan
kualitatif, yaitu mendeskripsikan dan menguraikan tentang pengaruh penggunaan media pembelajaran dalam dunia pendidikan. Teknik pengumpulan data yang digunakan dalam penelitian ini adalah studi kepustakaan (Library Research) dimana studi kepustakaan adalah kegiatan mengumpulkan bahan-bahan yang berkaitan dengan penelitian yang berasal dari buku, jurnal-jurnal ilmiah, literatur-literatur dan publikasi-publikasi lain yang layak dijadikan sumber untuk penelitian yang akan di teliti penulis, dengan cara mendeskripsikan dan menguraikan data tersebut adalah melalui beberapa pendapat para ahli. Variabel penelitian adalah segala sesuatu yang berbentuk apa saja yang ditetapkan oleh peneliti untuk dipelajari sehingga diperoleh informasi tentang hal tersebut kemudian ditarik kesimpulannya. Variabel yang digunakan dalam penelitian adalah Variabel Bebas (Independent Variable) dan Variabel Terikat (Dependent Variable). Maka dengan menggunakan pendekatan kualitatif penelitian ini diharapkan bisa memberikan fakta-fakta secara komprehensif tentang pengaruh penggunaan media pembelajaran dalam dunia pendidikan. Manfaat dari penulisan ini adalah untuk menambah wawasan bagi para pembaca mengenai pentingnya media pembelajaran dalam dunia pendidikan.

\section{Diskusi dan Pembahasan}

\subsection{Sejarah Pendidikan Multikultural}

Multikulturalisme (konsep hidup damai, setara, dan menerima kultur dan budaya yang berbedabeda) pertama kali muncul di Kanada, Amerika Utara. Pada abad 18 rakyat Amerika berhasil memenangkan Revolusi Amerika sekaligus berhasil mengusir suku Inggris yang tinggal di negara tersebut ke Amerika Utara (Yanuarti, 2020), yang kita kenal sekarang dengan sebutan negara bagian Amerika (Kanada).

Sistem pemerintahan Kanada adalah Demokrasi Parlementer merupakan negara monarki konstitusional yang dipimpin oleh Ratu Elizabeth II sebagai kepala tinggi negara. Dalam catatan sejarah negara Kanada merupakan negara paling kaya akan keberagaman kultur, imigran dari berbagai negara lain bebas masuk ke negara ini. Disamping itu dari sisi ekonomi, negara Kanada termasuk 10 besar negara paling sukses. Hal ini tidak lepas karena kekayaan alam yang melimpah bisa dikelola dengan baik dan pembinaan jaringan perdagangan internasional yang luas, utamanya dengan Amerika (Yanuarti, 2020).

Kanada negara pertama penganut paham multikulturalisme dan telah lama menerapkan dan mengajarkan pada dunia tentang pentingnya menghargai nilai-nilai keberagaman. Pada negara itu sejak beberapa tahun sebelumnya sekitar 1960 tinggal beberapa etnis imigran seperti inggris dan prancis dan mereka kerap berkonflik yang dipicu oleh perbedaan persepsi antar keduanya. Sejarah Multikulturalisme di Kanada dimulai sejak tahun 1971, dan pada tahun yang sama seluruh etnis yang tinggal di Kanada wajib menerima perbedaan kultur yang ada di dalamnya. kebijakan penerapan paham multikulturalisme digagas oleh pemerintah Kanada dan melahirkan aturan agar seluruh pihak yang berbeda secara budaya dan kultur mampu hidup damai dan berdampingan (Afandi, 2018).

Untuk memberikan solusi atas terjadi konflik berkepanjangan antar suku yang dipicu adanya perbedaan kultur pada negara tersebut, pemerintah Kanada pada tahun 1972 mendirikan Direktorat Multikultural melalui Departemen Luar Negeri yang pada akhirnya setelah kurun waktu cukup lama kurang lebih 17 tahun (setelah pendidikan multikultural diakui secara resmi oleh Kanada), tepatnya tahum 1988 melahirkan (Canadian Multiculturalism act) yang di dalamnya memuat poin-poin penting bagi keberlanjutan pendidikan multikultural selanjutnya. Adapun poin-poin (Canadian Multiculturalism act) meliputi hal-hal berikut (Afandi, 2018):

1) Alokasi dana untuk memajukan hubungan harmonis antar ras;

2) Memperluas saling pengertian kebudayaan yang berbeda;

3) Memelihara budaya dan bahasa asli;

4) Kesempatan yang sama untuk berpartisipasi, dan 
5) Pengembangan kebijakan multikultural di semua kantor pemerintah federal

Selanjutnya pendidikan multikulturalisme diimplementasikan di lembaga pendidikan formal, pada tahun 1977 didirikan lembaga pendidikan bahasa yang dikenal dengan (Ontario Heritage Language Programme) dengan tujuan pengajaran bahasa etnis sebagai jam tambahan (ektra kurikuler). Para guru kulit hitam (black population) diberikan penyuluhan agar selalu mengajarkan berprasangka baik dalam kehidupan. Sekolah dasar menengah seperti Alberta dan Saskacthewan diberikan ijin untuk mengajarkan bahasa kedaerahan masing-masing hingga $50 \%$ dari kurikulum resmi sekolah. Legalitas ini disambut gembira oleh para imigran yang tinggal di sana, diantaranya imigran Ukraina dan Jerman. Pada tahun 1993 para guru di sekolah diberi pelatihan tentang pendidikan multikultural oleh Vancouver School Board sebagai dewan sekolah. Dan sejak saat itu pula komite sekolah membentuk komite dan lembaga anti rasis yang merupakan bagian dari implementasi anti diskriminasi yang dibangun sejak dini pada anak didik (Afandi, 2018).

Namun demikian faktor kedekatan geografis dan jalinan ekonomi inten antara negara bagian Kanada dan Amerika, tak berlebihan bila ada yang menyatakan bahwa pendidikan multikultural merupakan gerakan reformasi pendidikan di Amerika pada tahun 1960, yang awalnya pendidikan di Negara tersebut terpola dalam bentuk "segregasi" atau pendidikan yang diklasifikasi menurut strata sosial, keagamaan yang dianut, dan kesukuan (Nurcahyono, 2018).

Banks membagi ada empat jenis dan fase perkembangan pendidikan multikultural di Amerika (Banks, 2002). yaitu:

1) Pendidikan yang bersifat segregasi yang memberi hak berbeda antara kulit putih dan kulit berwarna terutama terhadap kualitas pendidikan;

2) Pendidikan menurut konsep salad bowl, di mana masing-masing kelompok etnis berdiri sendiri, mereka hidup bersama-sama sepanjang yang satu tidak mengganggu kelompok yang lain;

3) Konsep melting pot, di dalam konsep ini masing-masing kelompok etnis dengan budayanya sendiri menyadari adanya perbedaan antara sesamanya. Namun dengan menyadari adanya perbedaan-perbedaan tersebut, mereka dapat membina hidup bersama. Meskipun masing-masing kelompok tersebut mempertahankan bahasa serta unsurunsur budayanya tetapi apabila perlu unsurunsur budaya yang berbeda-beda tersebut ditinggalkan demi untuk menciptakan persatuan kehidupan sosial yang berorientasi sebagai warga negara AS. Kepentingan negara di atas kepentingan kelompok, ras, dan budaya.

4) Pendidikan multikultural melahirkan suatu pedagogik baru serta pandangan baru mengenai praksis pendidikan yang memberikan kesempatan serta penghargaan yang sama terhadap semua anak tanpa membedakan asal usul serta agamanya. Studi tentang pengaruh budaya dalam kehidupan manusia menjadi sangat signifikan. Studi kultural membahas secara luas dan kritis mengenai arti budaya dalam kehidupan manusia.

Menurut Rosada, sejarah multikulturalisme adalah sejarah masyarakat majemuk (beragam budaya). Diantara negara-negara yang memberikan peluang dan perhatian lebih terhadap pengembangan pendidikan multikultural melalui paham multikulturalisme adalah Kanada, Amerika dan Australia. Rata-rata penghuni negara tersebut merupakan imigran dengan latar belakang kultur yang berbeda satu sama lainnya. Negara-negara tersebut merupakan contoh negara yang berhasil mengembangkan masyarakat multikultur dan mereka dapat membangun identitas kebangsaannya, dengan atau tanpa menghilangkan identitas kultur mereka sebelumnya, atau kultur nenek moyang tanah asalnya (Rosada, 2014).

Dari paparan singkat di atas, dapat dipahami bahwa Kanada negara pertama yang menghargai ragam budaya etnis dan suku di dalamnya. Disusul kemudian oleh Amerika dan Australia. Keberagaman budaya diakui seacara legal formal dan tertuang dalam undang-undang resmi pemerintah federal Kanada. Kanada memberikan kebebasan kepada penduduknya yang berlatar belakang etnis dan suku yang berbeda-beda dalam mengekpresikan nilai budaya yang diayakininya tanpa rasa takut akan ancaman dan pengkucilan. Negara Kanada menjadi titik balik berkembangnya pendidikan multikultural berdasarkan prinsip kesamaan hak dalam segala aspek dan bidang kehidupan, baik pendidikan, ekonomi dan politik. Lalu pada tahap berikutnya paham pendidikan multikultural ini berkembang di beberapa negara bagian Amerika dan negaranegara lain di belahan dunia, termasuk Indonesia.

\subsection{Urgensi Pedidikan Multikultural}

Menurut KBBI dalam pendidikan berasal dari kata di.dikv, men.di.dik $v$ memelihara dan memberi latihan (ajaran, tuntunan, pimpinan) mengenai akhlak dan kecerdasan pikiran: 
sedangkan pendidikan adalah pen.di.dik.an $n$ proses pengubahan sikap dan tata laku seseorang atau kelompok orang dl usaha mendewasakan manusia melalui upaya pengajaran dan pelatihan; proses, cara, perbuatan mendidik. Selanjutnya menurut Mardianto dalam Khairuddin dalam (2018) pendidikan berasal dari kata didik dalam bahasa Indonesia juga hasil dari transeletasi peng-Indonesia-an dari bahasa Yunani yaitu "Peadagogie". Estimologi kata Peadagogie adalah "pais" yang artinya "anak", dan "again" yang terjemahannya adalah "bombing". Jadi terjemahan bebas kata peadagogie berarti "bimbingan yang diberikan kepada anak". Menurut terminology yang lebih luas maka pendidikan adalah usaha yang dijalankan oleh seorang atau kelompok orang lain aga menjadi dewasa atau mencapai tujuan hidup dan penghidupan yang lebih tinggi dalam arti mental (Mardianto, 2012).

Menurut Salamwati dalam Khairuddin (2018) istilah pendidikan dari kata "didik" dengan memberinya awalan "pe" dan akhiran "an" yang mengandung arti "perbuatan". Dalam perkembanganya, istilah pendidikan berarti bimbingan atau pertolongan yang diberikan dengan sengaja terhadap anak didik oleh orang dewasa agar ia menjadi dewasa (Salminawati, 2011).

Adapaun tujuan penyelenggaraan pendidikan secara konferhenshif adalah untuk membangun moral bangsa, karenanya pemerintah Indonesia merumuskan undang-undang pendidikan nasional (UU RI No 20 Pasal 1 Ayayt 1 Tahun 2003 tentang sistem pendikan nasional) yaitu:

"Pendidikan adalah usaha sadar dan terencana untuk mewujudkan suasana belajar dan proses pembelajaran agar peserta didik secara aktif mengembangkan potensi dirinya untuk memiliki kekuatan spiritual keagamaan, pengendaliaan diri, kepribadian, kecerdasan, akhlak mulia, serta ketrampilan yang diperlukan dirinya, masyarakat, bangsa dan Negara".

Sedangkan multikulturalisme berasal dari akar kata kebudayaan. Secara etimologis multikulturalisme dibentuk dari kata multi (banyak), kultur (budaya), dan isme (aliran/paham). Dengan demikian multikulturalisme dapat diartikan sebagai sebuah paham yang mengakui adanya banyak kultur. Secara hakiki, dalam kata itu terkandung pengakuan akan martabat manusia yang hidup dalam komunitasnya dengan kebudayaannya masing-masing yang unik (Mahfud, 2006).

Sementara Suparlan (2002) dalam Afandi (2018) memandang kebudayaan dilihat dari fungsinya sebagai pedoman bagi kehidupan manusia. Multikulturalisme pada dasarnya adalah pandangan dunia yang kemudian dapat diterjemahkan dalam berbagai kebijakan kebudayaan yang menekankan penerimaan terhadap realitas keagamaan, pluralitas, dan multikultural yang terdapat dalam kehidupan masyarakat.

Menurut Azra (2007) multikulturalisme merupakan pandangan dunia yang harus diwujudkan dalam kesadaran berpolitik. Dengan kata lain kesadaran berpolitik harus dibangun dari pemahaman akan keragaman kultur, budaya dan agama dan kita bisa menerima dan menghargainya. Siapapun berhak menyatakan pendapat dan mendapatkan haknya tanpa melihat latar belakang etnis, suka bahkan agamanya.

Berdasarkan paparan di atas, pendidikan multikultural merupakan konsep atau pendekatan pendidikan yang targetnya tidak hanya memberikan pemahaman tentang keberagaman budaya dari etnis atau suku tertentu. Lebih dari itu, anak dididk diarahkan agar mampu menerima dan menghargai budaya orang lain yang berbeda dengan kebudayaan dirinya dalam konteks sosial dan kehidupan nyata. Barangkali tak berlebihan bila oleh Gus Dur semasa hidup sering membela kaum tertindas dan minoritas tanpa memandang agama dan suku. Itu yang disebut Gusdur Binneka Tinggal Ika.

\subsection{Implementasi Pendidikan Multikultural}

Konsep pendidikan multikultural dianggap sebagai sebuah gerakan pembaharuan dan proses untuk menciptakan lingkungan pendidikan yang adil dan proporsional tanpa pandang bulu. Implementasi pendidkan multikultural tentu tidak langsung siap saji.

Menurut Banks (2002), gerakan pendidikan multikultural merupakan gerakan reformasi lembaga-lembaga pendidikan agar memberikan peluang yang sama kepada setiap orang, tanpa melihat asal-usul etnis, budaya, dan jenis kelaminnya, untuk sama-sama memperoleh pengetahuan, kecakapan (skills), dan sikap yang diperlukan untuk bisa berfungsi secara efektif dalam negara-bangsa dan masyarakat dunia yang beragam etnis dan budaya. Lebih lanjut Banks menjelaskan awal mula lahirnya pendidikan multikultural di Kanada akibat adanya diskriminasi (baik secara non formal; dalam kontek kehidupan sosial kemasyaraktan maupun secara legal formal; diskriminasi dalam bentuk undangundang pemerintahan) yang dialami oleh 
beberapa etnis kelompok masyarakat AfroAmerika, Pribumi Amerika, Asia-Amerika dan Latino-Amerika.

Oleh karena itu, setelah pendidikan multikultural mengalami perjalanan panjang maka para ahli merekomendasi prinsip, tujuan, metode, pendekatan dan model pendidikan multikultural sebagai berikut:

a. Prinsip pendidikan Multikultural

Banks merekomendasikan beberapa prinsip pendidikan multikultural yaitu:

1) Pendidikan multikultural adalah gerakan politik yang bertujuan menjamin keadilan sosial bagi seluruh warga masyarakat tanpa memandang latar belakang yang ada.

2) Pendidikan multikultural mengandung dua dimensi: pembelajaran (kelas) dan kelembagaan (sekolah) dan antara keduaanya tidak bisa dipisahkan, tetapi justru harus ditangani lewat reformasi yang komprehensif.

3) Pendidikan multikultural menekankan reformasi pendidikan yang komprehensif dapat dicapai hanya lewat analisis kritis atas sistem kekuasaan untuk dapat dilakukan reformasi komprehensif dalam pendidikan.

4) Tujuan pendidikan multikultural adalah menyediakan bagi setiap siswa jaminan memperoleh kesempatan guna mencapai prestasi maksimal sesuai dengan kemampuan yang dimiliki.

5) Pendidikan multikultural adalah pendidikan yang baik untuk seluruh siswa, tanpa memandang latar belakangnya.

b. Tujuan Pendidikan Multikultural

Selanjutnya menurut Banks dalam Okta (2018) pendidikan multikultural memiliki empat tujuan, yaitu:

1) To help individuals gain greater self understanding by viewing themselves from the perspectives of other culture. Mengantarkan individu siswa agar mampu memahami diri sendiri secara utuh melalui perspektif budaya lain yang berbeda.

2) To provide student with cultural ethnic alternatives. Membekali siswa dengan pengetahuan tentang etnis dan budaya lain yang berbeda.

3) To reduce the pain and dicrimination that members of some ethnic groups experience because of their unique racial, physical, and cultural characteristic. Menghapuskan diskriminasi sebab perbedaan ras, warna kulit dan perbedaan karakter budaya.

4) To help students to master essential reading, writing, and math skill. Membantu siswa agar bisa paham dasar-dasar membaca, menulis dan berhitung.

c. Metode Pengajaran Pendidikan Multikultural Selanjutnya terdapat metode pengajaran yang ditawarkan dalam implementasi pendidikan multikultural menurut Allison CummingMcCann (2003) yaitu:

1) Metode Kontribusi;

Metode ini diterapkan dengan mengajak pembelajar berpartisipasi dalam memahami dan mengapresiasi kultur lain yang berbeda dengan dirinya. Dalam implementasinya yang lebih praktis, metode ini antara lain diterapkan dengan menyertakan peserta didik memilih buku bacaan bersama dan melakukan aktivitas bersama. Selain itu peserta didik juga diajak mengapresiasi event-event keagamaan maupun kebudayaan yang terdapat dalam kehidupan masyarakat. Pengampu pendidikan (kepala sekolah, guru) bisa melibatkan peserta didik di dalam pelajaran atau pengalaman yang berkaitan dengan event-event tersebut. Dalam hal tertentu peserta didik juga dapat dilibatkan untuk mendalami sebagian kecil dari kepelbagaian dari setiap tradisi kebudayaan maupun keagamaan;

2) Metode Pengayaan;

Metode ini memperkaya kurikulum dengan literatur dari atau tentang masyarakat yang berbeda kultur, etnis, atau agamanya. Penerapan metode ini, misalnya dengan mengajak peserta didik menilai atau menguji dan kemudian mengapresiasikan cara pandang masyarakat tetapi peserta didik tidak mengubah pemahamannya tentang hal itu, seperti tata cara atau ritual ibadah, pernak-pernik dalam ritual ibadah, pernikahan, dan lain-lain;

3) Metode Transformatif;

Metode ini memungkinkan peserta didik melihat konsep-konsep dari sejumlah perspektif budaya, etnik dan agama secara kritis. Metode ini memerlukan pemasukan perspektif-perspektif, kerangka-kerangka referensi dan gagasan-gagasan yang akan memperluas pemahaman pembelajar tentang sebuah ide. Jika ada metode pengayaan lebih banyak menggali titik temu dari etnisitas, budaya, dan agama, maka dalam metode transfomatif justru sebaliknya: menelanjangi nilai-nilai "negatif" dari budaya, etnik, dan juga agama; dan 
4) Metode Pembuatan Keputusan dan Aksi Sosial;

Metode ini mengintegrasikan metode transformasi dengan aktivitas nyata di masyarakat, yang pada gilirannya bisa berdampak terjadinya perubahan sosial. Peserta didik tidak hanya dituntut untuk memahami dan membahas isu-isu sosial, tapi juga melakukan sesuatu yang penting berkaitan dengan hal itu. Artinya, peserta didik tidak hanya berhenti pada penguasaan teori, tapi juga terjun langsung melakukan aksi-aksi nyata di masyarakat untuk menerapkan teori-teori yang mereka peroleh dari ruang pendidikan.

d. Pendekatan Pendidikan Multikultural

Mundzier Suparta (2008) juga merekomendasikan beberapa pendekatan pendidikan multikultural yang mungkin digunakan dalam pendidikan multikultural, sebagai berikut:

1) Pendekatan Historis. Pendekatan ini mengandaikan bahwa materi yang diajarkan kepada peserta didik dengan napak tilas ke belekang. Maksudnya agar pendidik dan peserta didik mempunyai kerangka berprikir yang komprehensif hingga ke masa silam untuk kemudian merefleksikan masa sekarang dan untuk masa mendatang. Dengan demikian materi yang diajarkan bisa ditinjau secara kritis dan dinamis;

2) Pendekatan Sosiologis. Pendekatan ini mengandaikan terjadinya proses kontekstualisasi atas apa yang pernah terjadi di masa lampau. Dengan pendekatan ini materi yang diajarkan bisa menjadi aktual, bukan karena dibuat-buat tetapi karena senantiasa sesuai dengan perkembangan zaman yang terjadi, dan tidak bersifat indoktrinasi karena kerangka berpikir yang dibangun adalah kerangka berpikir kekinian;

3) Pendekatan Kultural. Pendekatan ini menitikberatkan kepada autentisitas dan tradisi yang berkembang. Dengan pendekatan ini peserta didik bisa melihat mana tradisi yang autentik dan mana yang tidak. Secara otomatis peserta didik juga bisa mengetahui mana tradisi Arab dan mana tradisi yang datang dari ajaran Islam. Pendekatan kultural memungkinkan kita melihat lebih kritis antara tradisi masyarakat tertentu dengan ajaran keagamaan yang memamg berasal dari ajaran agama;
4) Pendekatan Psikologis. Pendekatan ini berusaha memperhatikan situasi psikologis personal secara tersendiri dan mandiri. Artinya masing-masing peserta didik harus dilihat sebagi manusia mandiri dan unik dengan karakter dan kemampuan yang dimilikinya. Pendekatan ini menuntut seseorang pendidik harus cerdas dan pandai melihat kecenderungan peserta didik sehingga ia bisa mengetahui metodemotode mana saja yang cocok untuk pembelajar;

5) Pendekatan Estetik. Pendekatan estetik pada dasarnya mengajarkan peserta didik untuk berlaku sopan dan santun, ramah, mencintai keindahan dan mengutamakan kedamaian. Sebab segala materi jika hanya didekati secara doktrinal dan menekankan adanya otoritas-otoritas kebenaran maka peserta didik akan cenderung bersikap kasar. Sehingga mereka memerlukan pendekatan estetik untuk mengapresiasi segala gejala yang terjadi di masyarakat dengan melihatnya sebagai bagian dari dinamika kehidupan yang bernilai seni dan estetis; dan

6) Pendekatan Berperspektif Gender. Pendekatan ini mencoba memberikan penyadaran kepada pembelajar untuk tidak membedakan jenis kelamin antara laki-laki dan perempuan. Sebab sebenarnya jenis kelamin bukanlah hal yang menghalangi seseorang untuk mencapai kesuksesan, melainkan kerja nyata yang dilakukannya. Dengan pendekatan ini, segala bentuk konstruksi sosial yang ada di lembaga pendidikan yang menyatakan bahwa perempuan berada di bawah laki-laki bisa dihilangkan.

e. Model Pendidikan Multikultural

Sementara menurut Tilaar (2004) terdapat 6 jenis model Pendidikan Multikultural yang bisa diimplementasikan dalam dunia pendidikan, yaitu:

1) Pendidikan "emergent society".

Model ini merupakan suatu upaya rekonstruksi dari keanekaan budaya yang diarahkan kepada terbentuknya budaya nasional.

2) Pendidikan kelompok budaya yang berbeda. Model ini merupakan suatu pendidikan khusus pada anak dari kelompok budaya yang berbeda. Tujuannya adalah memberikan kesempatan yang sama dengan mengurangi perbedaan antara sekolah dan keluarga, atau antara 
kebudayaan yang dikenalnya di rumah dengan kebudayaan di sekolah. Model ini bertujuan membantu anak untuk menguasai bahasa resmi serta norma dominan dalam masyarakat.

3) Pendidikan untuk memperdalam saling pengertian budaya.

Model ini bertujuan untuk memupuk sikap menerima dan apresiasi terhadap kebudayaan kelompok yang berbeda. Model ini merupakan pendekatan liberal pluralis yang melihat perbedaan budaya sebagai hal yang berharga dalam masyarakat. Di dalam kaitan ini, pendidikan multikultural diarahkan kepada memperkuat keadilan sosial dengan menentang berbagai jenis diskriminasi dan etnosentrisme.

4) Pendidikan akomodasi kebudayaan.

Tujuan model ini adalah mempertegas adanya kesamaan dari kelompok yang bermacam-macam. Mengakui adanya partikularisme dengan tetap mempertahankan kurikulum dominan.

5) Pendidikan "accomodation and reservation" Model ini berusaha untuk memelihara nilainilai kebudayaan dan identitas kelompok yang terancam kepunahan.

6) Pendidikan multikultural yang bertujuan untuk adaptasi serta pendidikan untuk memelihara kompetensi bikultural.

Model ini mengatasi pendekatan kelompok spesifik, identifikasi dan mengembangkan kemampuan untuk berkomunikasi secara cross-cultural dengan mendapatkan pengetahuan tentang bahasa atau kebudayaan yang lain.

Masing-masing prinsip, metode dan pendekatan serta model pendidikan multikultural di atas patut dicoba dalam penerapan pendidikan mutikultural di lapangan demi terciptanya kehidupan yang rukun, aman dan damai dalam tata kehidupan demi membangun Indonesia yang lebih baik dan bermarabat di kancah Internasional.

Pendidikan multikultural secara sederhana dapat dipahami sebagai konsep pendidikan yang berkeadilan sosial bagi seluruh komponen masyarakat tanpa membeda-bedakan satu sama lain karena unsur dan faktor tertentu semisal kesukuan, keagamaan, warna kulit dan sebagainya.

Implementasi pendidikan multikultural harus dikawal bersama-sama dan secara terbuka serta sukarela masing-masing perbedaan dihargai dan diakomudir. Dengan kata lain, tidak ada kelompok mayoritas yang semena-mena terhadap kelompok minoritas untuk alasan apapun yang tidak manusia. Perbedaan merupakan sunnatullah yang harus diterima oleh masing-masing kelompok dan mereka lebur atas nama kemanusiaan dalam kebersamaan penuh kesahajaan.

\subsection{Pendikan Islam Multikultural}

a. Pendidikan Islam

Sebagaimana telah dijelaskan di awal secara etimologi atau bahasa, pendidikan berasal dari kata didik, artinya bina. Mendapat awalan pen-, akhiran -an, yang maknanya sifat dari perbuatan membina atau melatih. Sedangkan dalam tinjaun bahasa Arab kata "pendidikan" sepadan dengan kata "Rabba". Disamping kata "rabba" dalam bahasa Arab terdapat kata "ta'lim" dan "ta'dim" yang secara fungional bisa diartikan mengajar (transfer ilmu) dan mendidik (membimbing), sehingga melahirkan manusia yang cakap secara intelektual dan matang secara sikap dan mental. Dan secara terminologi atau istilah pendidikan seperti yang dikatakan Basri, merupakan merupakan proses pembinaan, pelatihan, pengajaran dan semua hal yang merupakan bagian dari usaha manusia untuk meningkatkan kecerdasan dan keterampilannya (Basri, 2009). Sedang pendidikan Islam adalah proses pembinaan dan pembelajaran dilakukan guru terhadap anak didik berlandaskan nilai-nilai Islam. Dengan kata lain pendidikan Islam merupakan pendidikan yang didasarkan pada akidah, syariah, dan akhlak (Mudzakir, 2006).

Pendidikan Islam mengisyaratkan adanya tiga macam dimensi dalam upaya mengembangkan kehidupan manusia, yaitu:

1) Dimensi kehidupan duniawi yang mendorong manusia sebagai hamba Allah untuk mengembangkan dirinya dalam Ilmu pengetahuan, keterampilan dan nilai- nilai Islam yang mendasari kehidupan.

2) Dimensi kehidupan ukhrawi yang mendorong manusia untuk mengembangkan dirinya dalam pola hubungan yang serasi dan seimbang dengan Tuhan. Dimensi inilah yang melahirkan berbagai usaha agar seluruh aktifitas manusia senantiasa sesuai dengan nilai- nilai Islam.

3) Dimensi hubungan antara kehidupan duniawi dan ukhrawi yang mendorong manusia untuk berusaha menjadikan dirinya sebagai hamba Allah yang utuh dan 
paripurna dalam bidang ilmu pengetahuan dan keterampilan, serta menjadi pendukung dan pelaksana ajaran Islam.

Jika para ahli sepakat mengatakan akar dari kata multikulturalisme berasal dari kebudayaan dan ditinjau dari fungsinya adalah mengahargai perbedaan dalam kehidupan. Maka pendidikan Islam tidak menolak mengingkari fakta keberagaman budaya dalam kehidupan masyarakat. Hanya saja dalam pendidikan Islam terdapat prinsip-prinsip berikut :

1) Prinsip integrasi (tauhid). Prinsip ini memandang adanya wujud kesatuan dunia dan akhirat. Oleh karena itu, pendidikan akan meletakkan posisi yang seimbang untuk mencapai kebahagiaan di dunia sekaligus di akhirat.

2) Prinsip keseimbangan. Prinsip ini merupakan konsekuensi dari prinsip integrasi. Keseimbangan yang proporsional antara muatan ruhaniah dan jasmaniah, antara ilmu murni dan ilmu terapan, antara teori dan praktik, dan antara nilai yang menyangkut aqidah, syariah dan ahlak.

3) Prinsip persamaan dan pembebasan. Prinsip ini dikembangkan dari nilai tauhid, bahwa tuhan adalah Esa. Oleh karena itu, setiap individu dan bahkan semua mahluk hidup diciptakan oleh pencipta yang sama (Tuhan). Perbedaan hanyalah unsur untuk memperkuat persatuan. Pendidikan Islam adalah suatu upaya untuk membebaskan manusia dari belenggu nafsu dunia menuju pada nilai tauhid yang bersih dan mulia. Manusia, dengan pendidikan, diharapakan bisa terbebas dari belenggu kebodohan, kemiskinan, kejumudan dan nafsu kebinatangannya.

4) Prinsip kontinuitas dan berkelanjutan (istiqomah). Dari prinsip inilah dikenal konsep pendidikan seumur hidup (Iong life education). Di dalam Islam, belajar adalah satu kewajiban yang tidak pernah dan tidak boleh berakhir. Seruan membaca yang ada dalam AlQur'an merupakan perintah yang tidak mengenal batas waktu. Dengan menuntut ilmu secara kontinyu dan terusmenerus, diharapkan akan muncul kesadaran pada diri manusia akan diri dan lingkungannya, dan yang lebih penting tentu saja adalah kesadaran akan tuhannya.

5) Prinsip kemaslahatan dan keutamaan. Jika ruh tauhid telah berkembang dalam sistem moral dan ahlak seseorang dengan kebersihan hati dan kepercayaan yang jauh dari kotoran maka ia akan memiliki daya juang untuk membela hal-hal yang maslahat atau berguna bagi kehidupan. Sebab, nilai tauhid hanya bisa dirasakan apabila ia telah dimanifestasikan dalam gerak langkah manusia untuk kemaslahatan dan keutamaan manusia itu sendiri.

b. Pendidikan Islam

Secara sederhana, multikultural dapat berarti keragaman budaya (Lash, 2002). Istilah multikultural dibentuk dari kata multi yang berarti plural; banyak; atau beragam, dan kultur yang berarti budaya (Abdullah, 2005). Kultur atau budaya merupakan ciri-ciri dari tingkah laku manusia yang dipelajari, tidak diturunkan secara genetis dan bersifat khusus, sehingga kultur pada masyarakat tertentu bisa berbeda dengan kultur masyarakat lainnya (Yaqin, 2005).

Aspek keragaman yang menjadi esensi dari konsep multikultural dan kemudian berkembang menjadi gerakan yang disebut dengan multikulturalisme, merupakan gerakan yang bukan hanya menuntut pengakuan terhadap semua perbedaan yang ada, tetapi juga bagaimana keragaman atau perbedaan yang ada dapat diperlakukan sama sebagaimana harusnya. Dalam kaitan ini, ada tiga hal pokok yang menjadi aspek mendasar dari multicultural isme, yakni: Pertama, sesungguhnya harkat dan martabat manusia adalah sama. Kedua, pada dasarnya budaya dalam masyarakat adalah berbeda-beda, oleh karena itu membutuhkan hal yang Ketiga, yaitu pengakuan atas bentuk perbedaan budaya oleh semua elemen sosial-budaya, termasuk juga Negara (Wiwaha, 2015).

c. Karakteristik pendidikan Islam Multikulkural Pluralistik.

Keragaman telah menjadi bagian sejarah dan realitas kehidupan kemanusiaan, sehingga ia merupakan fenomena alamiah yang eksistensinya tidak dapat dipungkiri. Namun pada realitas konkret, keragaman telah menjadikan manusia terjebak pada sikap-sikap destruktif. Adanya konflik antar berbagai komponen masyarakat dengan latar belakang SARA (Suku, Agama, Ras dan Antargolongan). Salah satu cara dalam membentuk model kepemelukan inklusivistik terhadap agama adalah melalui promosi dan aplikasi Pendidikan Agama (Islam) berbasis multikultural pluralistic. Pelaksanaan pendidikan agama berbasis dan berwawasan multikultural pluralistik tersebut semakin dirasakan urgen 
dan mendesak jika dikorelasikan dengan kenyataan bahwa kemajemukan agama dan kemajemukan lainnya, seperti kemajemukan etnis, antar golongan dan kemajemukan lainnya belakangan ini telah menjadi suatu hal yang memancing eskalasi konflik yang sedemikian mengental pekat sebagaimana telah disinggung di atas. Pada sisi lain, kondisi pendidikan agama yang diajarkan di sekolah sangatlah memprihatinkan (Susanto, 2011).

Dengan demikian menurut Wiwaha (2015), aspek pokok yang sangat ditekankan dalam gerakan multikulturalisme adalah kesediaan menerima dan memperlakukan kelompok lain secara sama dan seharusnya sesuai dengan prinsip-prinsip kemanusiaan. Harkat dan martabat manusia yang hidup dalam suatu komunitas dengan entitas budayanya masingmasing (yang bersifat dinamis dan khas), merupakan dimensi yang sangat penting diperhatikan dalam gerakan multikulturalisame (Taylor, 1994).

Menurut Susanto (2006) Pendidikan agama (Islam) multikultural pluralistik adalah proses transformasi dan internalisasi nilai-nilai dasar dan ideal ajaran Islam yang berusaha mengaksentuasikan aspek-aspek perbedaan dan disparitas kemanusiaan dalam konteksnya yang luas sebagai suatu grand design of God (Sunnat Allah) yang mesti diterima dengan penuh arif dan lapang dada di tengah kenyataan kemanusiaan yang plural multikultural dalam segala dimensinya guna mewujudkan tatanan kehidupan yang berkeadilan (mardati Allah). Dengan definisi yang lebih operasional, dapat dinyatakan bahwa pendidikan agama (Islam) multikultural pluralistik merupakan usaha komprehensif dalam mencegah terjadinya konflik antar agama, mencegah terjadinya radikalisme agama, sekaligus pada saat yang sama memupuk terwujudnya sikap yang apresiatif positif terhadap pluralitas dalam dimensi dan perspektif apapun, karena pendidikan agama berwawasan multikultural pluralistik memiliki visi dan misi untuk mewujudkan agama pada sisi yang lebih santun, dialogis, apresiatif terhadap pluralitas dan peduli terhadap persoalan hidup yang komunal transformatif.

Menurut Baidhawy (2004) dalam susanto Karakteristik pendidikan Islam Multikulkural Pluralistik sebagai berikut:

1) Belajar hidup dalam perbedaan

2) Membangun saling percaya (mutual trust)

3) Memelihara saling pengertian (mutual understanding)
4) Menjunjung sikap saling menghargai (mutual respect)

5) Terbuka dalam berpikir

6) Apresiasi dan interdependensi

7) Resolusi konflik dan rekonsiliasi nirkekerasan.

d. Tantangan Pendidikan Agama Islam Multikultural Pluralistik

Tujuan pokok pendidikan adalah agar peserta didik secara aktif mampu mengembangkan potensi dirinya untuk memiliki kekuatan spiritual keagamaan, pengendalian diri, kepribadian, kecerdasan serta keterampilan yang diperlukan dirinya dan masyarakat. Pendidikan tidak hanya memberikan pengajaran keahlian khusus (spesialisasi), tetapi juga pemberian pengetahuan, pertimbangan, kebijaksanaan dan kearifan kepada peserta didik. Untuk sampai pada titik ini, pendidikan mesti diberikan dengan basis saling menghargai dan menghormati keberbagaian atau keragaman (pendidikan multikultural).

Indonesia sebagai negara yang memiliki multikulturalitas tinggi, semestinya menerapkan pendidikan agama Islam-dan juga pendidikan keagamaan lainnya-yang berwawasan multikultural pluralistik, sehingga output-nya adalah terbentuk peserta didik yang memiliki wawasan dan sikap multikultural dengan indikator berusaha melaksanakan nilainilai multikultural-pluralistik dalam hidup kesehariannya atas dasar pandangan hidup yang berorientasi bahwa keragaman dalam aspek apa pun merupakan sesuatu yang tidak dapat ditolak eksistensinya sehingga mesti diapresiasi secara arif positif. Dalam istilah Nurcholish Madjid bersikap arif positif terhadap kebhinekaan adalah diwujudkan dengan pemahaman bahwa pluralitas tidak dipandang sebagai kebaikan negatif (negative good) yang kegunaannya hanya ditilik dari aspek penyingkiran fanatisisme, melainkan lebih dipahami sebagai genuine engagement of diversities within the bond of civility (pertalian sejati keragaman dalam ikatan-ikatan keadaban) bahkan pluralitas merupakan suatu keharusan bagi keselamatan umat manusia melalui mekanisme pengawasan dan pengimbangan di antara sesamanya sehingga mewajibkan tatanan kehidupan toleran, terbuka dan menjunjung tinggi supremasi hukum (Baso, 1999).

Ada beberapa tantangan dalam praktek pendidikan Islam multikultral yaitu (Suparta, 2003):

1) Konformisme 
2) Sumber daya manusia guru

3) Perubahan sosial politik

4) Radikalisme atau fundamentalisme

5) Perubahan orientasi

6) Globalisasi

Memang dari sekian banyak rintangan dan tantangan dalam pelaksanaan pendidikan multikultural, harapan paling tinggi untuk mensukseskan ada pada guru. Dan melihat fakta di lapangan banyak guru yang belum siap untuk mempraktekkan pendidikan multikultural. Sementara keberhasilan pendidikan mltikultural ini sepenuhnya ada pada kesiapan guru baik dari sisi konten, metode dan strategi pembelajaran dengan keterlibatan dan dukungan kepala sekolah. Disamping itu dalam pengajaran nilai-nilai multikultural para guru dituntut harus mampu mengatur kegiatan sekolah yang diterjemahkan ke dalam konten, proses, dan situasi sehingga setiap siswa dari berbagai suku, agama, dan gender pada akhirnya bisa menghormati perbedaan, dan dapat mengembangkan diri. Pendidikan multikultural misal tentang ragam suku, budaya, dan agama harus diperkenalkan sejak dini bahkan kepada siswa tingkat paling dasar/taman kanak-kanak (TK). Asusmsinya semakin awal diperkenalkan dan bahkan pada tingkat yang paling dasar maka semakin kuat peluang untuk mensukseskan pendidikan multikultural.

\section{Penutup}

Pendidikan multikultural tetap menjadi isu penting dewasa ini, apalagi kondisi sosial dihadapkan pada tantangan gerakan radikalisme yang semakin terbuka. Pendidikan multikultural dapat dijadikan sebagai gerakan anti radikalisme. Tulisan ini mengurai permasalahan pendidikan multikultural di Pesantren Bali Bina Insani. Secara konsep, pendidikan multikultural di Pesantren Bali Bina Insani (BBI) ditandai dengan civitas yang beragam. Terdapat guru dan pegawai Muslim dan non Muslim (Hindu). Santri-santri juga beragam. Materi pelajaran bersifat inklusif-toleran. Pendekatan dan strategi pembelajarannya variatif. Evaluasinya komprehensif. Lingkungannya plural. Pesantren BBI menghargai perbedaan dan mengedepankan persamaan. Ia memiliki wawasan, sikap dan perilaku toleransi organik. Pendidikan multikultural didesain sebagai strategi adaptasi di daerah minoritas Muslim. Melalui pendidikan multikultural, Pesantren BBI diterima dengan baik oleh masyarakat Hindu. Ia tumbuh berkembang secara kelembagaan; adanya jalinan kerjasama sosial antara masyarakat dengan Pesantren BBI; masyarakat berpartisipasi dalam mengontrol perilaku santri. Respon masyarakat juga baik, mereka hidup rukun dan saling bekerjasama secara mutual simbiosis.

\section{Referensi}

Muâ, A. (2016). Memaknai Kembali Multikulturalisme Indonesia Dalam Bingkai Pancasila. JPK (Jurnal Pancasila Dan Kewarganegaraan), 1(1), 34-40.

Mujib, A., \& Mudzakkir, J. (2006). Ilmu pendidikan islam. (Jakarta: Kencana, 2006), 15

Syaifuddin, A. F. (2006). Membumikan multikulturalisme di Indonesia. Jurnal Antropologi Sosial Budaya ETNOVISI, 2(1), 310

Afandi, (2018) Mewujudkan Pendidikan Multikultural Di Indonesia. Sebuah Kajian Pendidikan Multikultural di Berbagai Negara, Wawasan Makro Pendidikan, 3(2).

Baso, A. (1999). Civil society versus masyarakat madani: arkeologi pemikiran" civil society" dalam Islam Indonesia. Pustaka Hidayah

Khairuddin, A. (2018). Epistemologi pendidikan multikultural di Indonesia. IJTIMAIYAH Jurnal Ilmu Sosial dan Budaya, 2(1).

Cumming-McCann, A. (2003). Multicultural education: Connecting theory to practice. Focus on Basic, 6.

Azyumardi Azra, (2005) Pendidikan Agama, dalam Membangun Multikulturalisme Indonesia dalam Pendidikan Agama Berwawasan Multikultural (Jakarta: Gelora Aksara Pratama).

Azra, A. (2003). Bali and Southeast Asian Islam: debunking the myths. In After Bali: The Threat of Terrorism in Southeast Asia (pp. 39-57).

Taylor, C. (1994). The politics of recognition (pp. 25-74). Princeton University Press.

Choirul Mahfud, (2006). Pendidikan Multicultural. (Yogyakarta: Pustaka Pelajar)

Rosyada, D. (2014). Pendidikan multikultural di Indonesia sebuah pandangan konsepsional. SOSIO-DIDAKTIKA: Social Science Education Journal, 1(1), 1-12.

Disampaikan oleh Prof. Maskuri Bakri, Rektor Universitas Islam Malang (UNISMA), dalam 
Seminar Nasional bertema "Kebebasan Beragama dan Berpikir Multikulturalisme untuk Membangun Stabilitas Bangsa" di Gedung Usman bin Affan (15/03/2017), dalam Surya Malang, (15 Maret 2017).

Putri, D. C. (2020, February). Harmony in Diversity: The Implementation of Multicultural Education at Indonesian Schools. In 2nd International Conference on Social Science and Character Educations (ICoSSCE 2019) (pp. 168-172). Atlantis Press.

Edi Susanto, (2011). Pemikiran Nurcholish Madjid tentang Pendidikan Agama Islam Multikultural Pluralistik (Perspektif Sosiologi Pengetahuan), Disertasi, Program Pascasarjana Institut Agama Islam Negeri Sunan Ampel Surabaya, 12-13.

Susanto, E. (2006). Pendidikan Agama Berbasis Multikultural. Karsa: Jurnal sosial dan Budaya. XI, (1.2006), 784.

Turmudi, E., \& Sihbudi, M. R. (2005). Islam dan radikalisme di Indonesia. Yayasan Obor Indonesia.

H.A.R Tilaar, Manajemen Pendidikan Nasional, (Bandung: P.T Remaja Rosdakarya, 2004)

H.A.R. Tilaar, (2004). Multikulturalisme: Tantangan-tantangan Global Masa Depan dalam Tranformasi Pendidikan Nasional, (Jakarta: Grasindo), 123-124.

J.A. Banks, (2002). An Introduction to Multicultural Education, (Boston: Allyn and Bacon).

M. Ainul Yaqin, (2005). Pendidikan Multikultural (Cross-Cultural Understanding untuk Demokrasi dan Keadilan), (Yogyakarta: Pilar Media).

M.Amin Abdullah, (2005). Pendidikan Agama Era Multi Kultural Multi Religius, (Jakarta: PSAP Muhammadiyah)

M.Quraish Shihab, (1998). Wawasan Al-Quran: Tafsir Maudhu'i atas Pelbagai Persoalan Umat, (Bandung: Mizan)

Mardianto, (2012). Psikologi Pendidikan: Landasan untuk Pengembangan Strategi Pembelajaran, (Medan: Perdana Publishing)

Hilmy, M. (2013). Whither indonesia's islamic moderatism? A Reexamination on the Moderate Vision of Muhammadiyah and NU. Journal of Indonesian Islam, 7(1), 24-48..
Moh. Roqib, (2009). Ilmu Pendidikan Islam, Pengembangan Pendidikan Integratif di Sekolah, Keluarga dan Masyarakat, (Yogyakarta: Lkis).

Muchlis M. Hanafi, (2013). Moderasi Islam: Menangkal Radikalisasi Berbasis Agama (Jakarta: Ikatan Alumni al-Azhar dan Pusat Studi Al-Qur'an)

Mundzier Suparta, (2008). Islamic Multicultural Education: Sebuah Refleksi atas Pendidikan Agama Islam di Indonesia, (Jakarta: Ghazali Center).

Noorhaidi Hasan, (2012). Islam Politik di Dunia Kontemporer: Konsep, Genealogi dan Teori, (Cet. I; Yogyakarta: Suka-Press)

Nurcahyono, O. H. (2018). Pendidikan multikultural di Indonesia: Analisis sinkronis dan diakronis. Habitus: Jurnal Pendidikan, Sosiologi, \& Antropologi, 2(1), 105-115.

Parsudi Suparlan, (2002). Menuju Masyarakat Indonesia yang Multikultural, 98. Keynote Address yang disajikan dalam Sesi Pleno I pada Simposium Internasional Jurnal ANTROPOLOGI INDONESIA ke-3: "Membangun Kembali Indonesia yang Bhinneka Tunggal Ika: Menuju Masyarakat Multikultural", (Universitas Udayana, Denpasar, Bali).

Salminawati, S. (2011). Filsafat pendidikan islam: Membangun konsep pendidikan yang islami.

Scott Lash dan Mike Featherstone (ed.), (2002). Recognition and Difference: Politics, Identity, Multiculture, (London: Sage Publication).

Suharto, T. (2017). Indonesianisasi Islam: Penguatan Islam Moderat dalam Lembaga Pendidikan Islam di Indonesia. Al-Tahrir: Jurnal Pemikiran Islam, 17(1), 155-178.

Ghafur, W. A. (2005). Tafsir Sosial: Mendialogkan Teks dengan Konteks. elsaq press.

Wiwaha, W. A. (2015). Pengembangan Pendidikan Islam Multikultural. El-Hikam, 8(2), 211-232.

Yanuarti, E., \& HS, D. P. S. (2020). Analisis Perbandingan Pendidikan Multikultural (Indonesia, Amerika, Kanada, Inggris). AtTa'lim: Media Informasi Pendidikan Islam, 19(1), 46-65. 